\title{
GUARIANTHE, A GENERIC NAME FOR THE "CATTLEYA" SKINNERI COMPLEX
}

\author{
Robert L. Dressler ${ }^{1}$ \& Wesley E. HigGins ${ }^{2}$
}

\author{
${ }^{1}$ Missouri Botanical Garden; Florida Museum of Natural History; Marie Selby Botanical Gardens \\ Mailing address: 21305 NW 86th Ave., Micanopy, Florida 32667, U.S.A. rdressl@nersp.nerdc.ufl.edu
}

${ }^{2}$ Marie Selby Botanical Gardens, 811 South Palm Avenue, Sarasota, FL 34236-7726, U.S.A. whiggins@selby.org

Molecular systematics, the comparison of DNA sequences, has brought a continuing revolution to plant taxonomy. In most cases, the results are intuitively reasonable, even when they demand changing long-known names. The analysis of the Laeliinae, by van den Berg et al. (2000) has confirmed some clear relationships, showing, for example, that Schomburgkia is quite distinct from Myrmecophila but very close to Laelia anceps. Among other things, this study has shown that Cattleya, as we have known it, is not clearly delimited. One of the clearest segregates is the largely Central American "Cattleya" skinneri complex (van den Berg 2000). With the removal of this group from Cattleya, most of the remaining species form a natural group, with some South American misfits, all quite unlike the skinneri complex. As it is now clear that C. skinneri and its close allies are out of place in Cattleya, the present paper proposes a new generic name for this complex, Guarianthe, based on Guaria, a Costa Rican word for orchid, and the Greek anthe, or flower. Guaria, by itself, might be confused with the Meliaceous Guarea.

According to the molecular analysis by van den Berg et al. (2000), the sister group of the C. skinneri alliance is Rhyncholaelia. There is no bootstrap support for combining these two groups, and, indeed, the bootstrap support for C. skinneri, C. patinii and $C$. aurantiaca as a group is minimal. Guarianthe is quite distinct from Rhyncholaelia in most features. Guarianthe has a racemose inflorescence, the pollinia are four, and the cuniculus type nectary is quite small, while the inflorescence of Rhyncholaelia is sessile and one-flowered, the pollinia are eight, and there is a very prominent nectary separating the ovary from the rest of the flower, so the fruit is long-beaked.
Though Cattleya bowringiana is not placed within the $C$. skinneri alliance in the molecular analysis, there is also no bootstrap support to exclude it from the clade. We treat $C$. bowringiana as a member of Guarianthe because of the strong agreement in all structural features. Further analysis may falsify this conclusion, but, in the meantime, we may call $C$. bowringiana a Guarianthe.

There is a special problem involving the hybrid swarm between $C$. aurantiaca and C. skinneri. Plants from this hybrid swarm have been described as new, including Cattleya deckeri Klotzsch, C. guatemalensis Moore, C. pachecoi Ames \& Correll, C. skinneri var. parviflora Hook., and apparently Cattleya laelioides Lemaire (Withner 1999). Withner suggests that the name $C . \mathrm{x}$ guatemalensis should be conserved for the members of this hybrid swarm (1999), so we refrain from publishing any new combination based on the hybrid swarm. Both Rolfe (1900) and Withner (1999) hold that $C$. deckeri is the oldest name for $C$. patinii, a species widespread in northern South America. The available evidence suggests, however, that $C$. deckeri was based on a hybrid backcross to $C$. skinneri (Dressler 1998).

Guarianthe Dressler \& W.E. Higgins, gen. nov.

Plantae pseudobulbis claviformibus, bifoliatis, inflorescentia racemosa terminalis, labello columnam parvam involvens.

Epiphytic, pseudobulbs clavate, bifoliate; inflorescence terminal, racemose, from a prominent sheath; sepals and petals similar, lip infundibuliform, surrounding the column; column clavate, $10-12 \mathrm{~mm}$ long; anther incumbent, pollinia 4, with caudicles.

Type species: Cattleya skinneri Bateman. 
Guarianthe aurantiaca (Bateman ex Lindl.) Dressler \& W.E. Higgins, comb. nov.

Basionym: Epidendrum aurantiacum Bateman ex Lindl., Edward's Bot. Reg. 24: misc. p. 8. 1838.

Guarianthe bowringiana (Veitch) Dressler \& W.E. Higgins, comb. nov.

Basionym: Cattleya bowringiana Veitch, Gard. Chron. 2: 683. 1885.

Guarianthe skinneri (Bateman) Dressler \& W.E. Higgins, comb. nov.

Basionym: Cattleya skinneri Bateman, Orchid. Mex. Guat. t. 13. 1838.

Guarianthe patinii (Cogn.) Dressler \& W.E. Higgins, comb. nov.

Basionym: Cattleya patinii Cogn. Dict. Icon. Orchid. 2: t. 25. 1900.
LITERATURE CITED

van den Berg, C. 2000. Molecular phylogenetics of Tribe Epidendreae with emphasis on Subtribe Laeliinae (Orchidaceae). Ph.D. thesis, Department of Botany, University of Reading.

van den Berg, C., W.E. Higgins, R. L. Dressler, W.M. Whitten, M.A. Soto Arenas, A. Culham, \& M.W. Chase. 2000. A phylogenetic analysis of Laeliinae (Orchidaceae) based on sequence data from internal transcribed spacers (ITS) of nuclear ribosomal DNA. Lindleyana 15: 96-114.

Dressler, R.L. 1998. The neotypification of Cattleya deckeri. Lindleyana 13: 219-220.

Rolfe, R. A. 1900. Cattleya deckeri. Orchid Rev. 8: 261263.

Withner, C.L. 1999. Cattleya $\times$ guatemalensis. Its history, close relatives, and problems relating to its identity. Orch. Dig. 63: 53-61.

Robert L. Dressler nació en el centro de los EE.UU., en la Sierra de Ozark, en 1927, y salió a la civilización (California) a la edad de 10 años. Desde sus años formativos, sentía mucho interés en el campo y en la naturaleza. En la universidad, la combinación de una profesora mediocre de zoología y un profesor excelente de botánica le guió definitivamente hacia la botánica. Recibió el Doctorado en Biología de Harvard en 1957, y trabajó en el Jardín Botánico de Missouri de 1957 a 1963, cuando fue al Instituto Smithsoniano de Investigaciones Tropicales. Vivió algo más de 20 años en Panamá, estudiando la clasificación y la ecología de orquídeas, especialmente su polinización natural. Ahora vive en el norte de Florida, asociado con el Jardín Botánico de Missouri y el Herbario de la Universidad de Florida. Ha escrito varios libros y numerosos artículos. Ahora está trabajando en el proyecto Flora Mesoamericana.

Wesley E. Higgins is currently the Head of Systematics and Jessie B. Cox Chair in Tropical Botany at Marie Selby Botanical Gardens in Sarasota, Florida. He is also a Courtesy Curator at the Florida Museum of Natural History. Dr. Higgins is a member of the International Scientific Committee of LANKESTERIANA and is on the Editorial Board for Selbyana. He has previous experience at Royal Botanic Gardens, Kew, and Missouri Botanical Garden. Dr. Higgins graduated magna cum laude from the University of Florida, earning a Ph.D. in Horticulture Science with a minor in Botany. Although his research is in the holomorphology of Encyclia sensu lato, he is better known for its segregated genera such as Prosthechea, Oestlundia, Microepidendrum, and Dinema. He is an accredited American Orchid Society judge and an approved AOS taxonomic authority. 